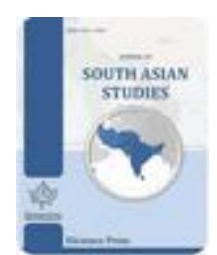

Available Online at EScience Press

Journal of South Asian Studies

ISSN: 2307-4000 (Online), 2308-7846 (Print)

https://esciencepress.net/journals/JSAS

\title{
WORKING ABROAD WHILE FAMILIES AT HOME: NEGOTIATING PATRIARCHAL ROLE FOR WOMEN IN SOUTH ASIA: A CASE STUDY OF GOPALGANJ DISTRICT OF BIHAR, INDIA
}

\author{
Muskan Mustaqeem* \\ Centre for West Asian Studies, Jamia Millia Islamia, New Delhi-110025, India. \\ *Corresponding Author Email ID: muskanjmi16@gmail.com
}

\begin{abstract}
A B S T R A C T
In recent times, South Asia has emerged as the highest emigrant sending region to the Gulf. According to the United Nations Population Division (2017) 20.3 million stocks of migrants is in the Gulf countries, among the total number of South Asian migrants were 13millions which accounted for 63.9 percent of the total number of stock of migrants in the Persian Gulf. Due to this huge outpouring of workers, the region has also emerged as the largest receiver of remittances. It is interesting to note that these South Asian migrants are generally from the strata of societies where patriarchal structures are still in their rigidities as modernity has not yet penetrated there to change the feudal mentality, especially towards assigning women's role in society. Patriarchy defines a limited socio-economic role for women. They undergo inflexible social processes and remain disadvantaged often affecting their rights, social status, mobility, autonomy, and decision-making capabilities. The physical absence of their husbands, the heads of the home, and the influx of remittance have positively impacted the lives of these women as they are now able to renegotiate their social roles and responsibilities. The process has helped to loosen the rigidities of the patriarchal structure. The objective of the research is to find out how the truancy of men has transformed and emancipated/empowered women in home countries. This study examines the literature on the socio-economic impact of male migration, and how it affects women's mobility and empowerment in left-behind families. This qualitative research evaluates women's empowerment through one independent variable i.e., husband's emigration, and three dependent variables, women's decision-making power, mobility, and autonomy in the absence of their husbands within the framework of gender empowerment. For the convenience of this research, 50 samples of Gulf emigrants' families living in the Gopalgunj district of Bihar, India have been selected (Data is collected from the field through informal and conversational interviews, questionnaires, and convenience sampling is used). This research argues that a significant social transformation in gender roles has occurred due to husbands' migration.
\end{abstract}

Keywords: Labor Migration from India, South Asia, West Asia, immigration, Emigration, Gulf Wives, Women empowerment.

\section{INTRODUCTION}

The South Asia male workers outflow to the Gulf region has now become a contemporaneous phenomenon with the heavy unskilled and skilled/semi-skilled laborers mostly, working on a temporary contract in construction sides, services, and domestic care sectors. Most of these South Asian nationals registering for employment in the Gulf countries are males and various data indicates that most of these migrant workers are highly 'unskilled' (International Labour Organization, 2018). These South
Asian migrants are generally from the lower strata of societies, and migration as a process is deeply seated in their lives for living a prosperous life. Most of these migrants are young and married; belong to the lower class and rural areas. When these young laborers migrate, they leave their families behind and continually transfer earned money back to them. This migration of lower-class laborers to the Gulf Countries has an enormous impact on their socio-economic life and on the economy of their home country (Zachariah et al, 2000). 
Migration, in these societies, is gendered and gendering specific as women hardly participate in the process (Hondagneu-Sotelo, 1992). This whole process of migration is being called gendered because it is linked with the recognition of male out-migration and latter is associated with capacitating wives/women to make household decisions, in handling remittances, and in nurturing their agency and autonomy in the absence of their husbands/head of the family. Modernity has not yet penetrated in the rural societies of South Asia to change patriarchal structures and their rigidities and the gendered notion of migration. However, the male migration process has an impact on the families left behind by their husbands as it provides a condition facilitating them to negotiate the gendered notions of patriarchal work division and to challenge the publicprivate dichotomy.

As (Hondagneu-Sotelo, 1992) in her study "Overcoming Patriarchal Constraints: The Reconstruction of Gender Relations among Mexican Immigrant Women and Men" argued that process of migration helps Mexican women to reconstruct patriarchy. Throughout the process, patriarchal gender relations are conducive in organizing migration at the family stage and long-winded separations with migrant's wives amend shapes of patriarchal authority and the traditional gendered household division of labor. In her study, "In the absence of their men: the impact of male migration on women" in Kerala by Leela (Gulati, 1993) focuses on the ten different migrant wife's profiles and examines various issues that arise when their men migrate abroad and how they manage their family and work responsibilities in their absence and Geeta (Menon, 1995) in her study on "The Impact of Migration on the Work and Status of Tribal Women in Orissa" has found that due to migration of their male counterparts, women's mobility outside their family has increased, and they are able to handle more household responsibilities, and utilize remittances and resources. She further argues that these women have emerged as a leader in supervising and managing new roles and responsibilities, and due to their separation from their spouses, a structural transformation has occurred, this also has led their males to migrate without any constraints.

Migration, particularly from Bihar to the different parts of the country and to the world, has become perpetual in life, and in the way of living of the people. Traditionally, labor migration throughout history has been male preserve and marriage was the predominant reason for females to migrate. When these males migrate for employment, they leave their families behind. The most research literature on migration has grown diversely which focuses on the various unfurling intricacies on the process of migration, origin, and the destination of place, some studies conducted from an economic perspective (De Haan, 2002) (Deshingkar \& Start, 2003) and on seasonal migration (Ghosh \& Sharma 1995) from Bihar. Some significant studies have been conducted from Kerala state which discusses the impact of male migration on families in detail especially on women, but very little research attention has been given on leftbehind women particularly for second-largest sending laborer state of India. Few of those are done by (Jetley 1987), (Desai \& Banerji, 1995), and (Roy, 2011). Their work is mostly based on comparative analysis between migrant and non-migrant women which mainly focuses on the decision-making power within the family and women's mobility. These studies do not discuss much how their husband's truancy had made an impact on these women in renegotiating gender roles and patriarchy. A common peculiarity in the lives of these left-behind women is that they are mainly restricted to the home boundaries with limited mobility. Predominantly, they are placed in the role of homemaker and child-bearer. Furthermore, patriarchy and various hierarchical practices imposed on women lead them excluded from the public sphere, decisionmaking in the family, and mobility. Therefore, this paper will mainly focus on how migration as a factor had reshaped gender roles and negotiated the patriarchy and how the truancy of the male heads leads to the transformation of gender roles. The paper will try to answer these questions: Does male migration influence women's mobility, autonomy, and decision-making? Does male migration as a process influences patriarchy? Are women able to renegotiate their social roles and responsibilities? The paper is based on the empirical study conducted in the Gopalganj district of Bihar, India. This study is based on both open-ended and structured interviews and questionnaires to non-migrant women who were left behind (whose husband is migrated to the Gulf country) in the selected five villages of the Gopalganj district. A total of 50 household profiles were interviewed in - Tribirwan, Indarwan, Nawada, YakoodTakia, and Gopalganj (Town area). This paper is divided into three parts. The first part of the paper will 
trace the brief history of migration from Bihar and its nature of society. The second part talks about SocioEconomic and demographic profile of sample households in the interviewed villages. The last part is based on the empirical analysis of the study, and I will elucidate the above research questions through the case study of Gopalganj district, Bihar.

\section{HISTORICAL BACKGROUND OF MIGRATION}

Bihar is an Indian State, located in the northern region of the country. The state has the 3rd largest population with a growth rate of 25 percent which exceeds the national average of about 17 percent (Census 2011). For centuries, people have been experiencing male labor out-migration. In the case of Eastern U.P (Uttar Pradesh) and Bihar, there is definite evidence of male indentured workers migrating to several French and British colonies such as Mauritius, West Indies, and Fiji, and many other countries during the 18th and 19th centuries. Among 38 districts of Bihar, Gopalganj is situated on the West North corner and second-highest laborer sending and second-largest remittance-receiving district to the Gulf region, after Siwan district. Bihar is largely a rural agrarian society, with feudalism and caste consciousness, deep-rooted traditional beliefs and practices, and gender bias against females persist to exist. The evident social stratification has created many unfavorable conditions for females. The literacy rate was recorded lowest for the State at 63.8 percent, which is lower than the national average, and the female literacy rate is at 53.3 percent significantly lower as compared to the male literacy rate which is 73.5 percent (Census, 2011). The existing poor living conditions, widespread poverty, and annual flood scenarios in many north districts of the states forced people to migrate.

Migration is a continual historical reality of Bihar since times immemorial and progressively becoming more and more intensive in the lives of people of Bihar due to prevailing economical and agricultural scenarios which make it ineffectual to sustain their life. The socioeconomic compulsion and emotional pains of separation from their loved ones are articulated through folktales (folk songs) and theatres of the people from the Bihar region of India. There are numerous folk songs on migration that are majorly in female voices. These migration songs tell us about 'tales of loneliness', 'pain of separation', and the everyday reality of male migrant and his left-behind wife, and they also tell us how migration had impacts on the lives of women. The most prevalent folklore is 'bidesia', (sung through female voice) where the migrant is introduced as a bidesia or pardesia (male person who leaves for work to different parts of the country or abroad), and the other elements of the folk song show strong fondness with their loved ones who are going to leave them behind, so they curse the conditions that caused the separation. These folk songs on Bihar migration can be an important cultural source to understand the impact of male migration on left-behind families, and to trace the antiquity of migration in Bihar.

A significant number of migrants from Bihar have been migrated within and outside India to earn their livelihood in several occupations, due to the persistent existing problems of unemployment and poverty in the State which makes them incapable to sustain the outlays of their families. Whilst, lack of major industries and conventional pattern of farming create a surplus of labor, this surplus labor must migrate elsewhere to earn their livelihood. After the Oil boom of the 1970s in Gulf countries, these six countries emerged as a destination of employment for these laborers. These migrant workers come from the lower strata of societies where patriarchal structures are still in their rigidities as modernity has not yet penetrated there to change the feudal mentality, especially towards assigning women's role in society but now the migration is playing a liberating role for them as the study will demonstrate.

\section{SOCIO-ECONOMIC PROFILE OF SAMPLE HOUSEHOLD}

This part of the paper deals with the general composition, socio-economic and demographic features of sample households. For this purpose, through fieldwork primary data was collected like wives age, migrants age, educational level of both the migrant and non-migrant wives, type of house, type of family system, wife's occupation, migrant's occupation, income, number of children, property owned by migrants and nonmigrant wives, religion, vehicle owned and household goods \& appliances they owned, were taken into consideration for the general information about the sample household in the study area.

The study area is largely Hindu dominated (83 percent) and most of the migrants' families belong to the Muslim religion which constitutes only 17 percent of the population in the district. In our sample profile, 42 profiles belong to Muslim families and 8 were Hindu 
families. Out of 50 households, 18 (36 percent) families belong to the nuclear family system (i.e., wife and children) and 32 were living in an extended family system (i.e., wife, children, migrant husband's older parents, or with or without migrant husband's unmarried brother or sister). Among most migrant families were recorded living in rural villages and less than 12 percent were living in a semi-urban area in Gopalganj district. Thus, it can be noticed that Muslims pre-dominated migration to these six Gulf countries despite the fact they share a low percentage of the total population in the Gopalganj district. It was also noticed that these Muslim migrants' profiles have superiority over moving to Gulf countries for employment for several reasons. One of the reasons is the low educational background of Muslim migrants. Most of the Muslim migrants were working as blue-collar workers in the Gulf countries.

Age is an important component that indicates the physical and psychological wellbeing of human beings as their socio-economic activities are very much influenced by it. Most migrated husbands were above the age of 45 years of age, 36 percent belongs to the Age between 36 years to $45 y e a r s$. Only 9 migrants were less than the age of 30 and were considered as the youngest in all groups but the lowest in number. Whilst in the case for nonmigrant wives, most of the wives' age falls under the category of age between 31 years to 45 years old (46 percent), 30 percent were youngest with an age of less than 30 . These young and middle-aged women were recorded mostly living with under migrant parent's headship. The average age for both migrated husbands and non-migrated wives was above 45 and between 31 years to 45years respectively. For migrants, this is so because they were working and living in the Gulf countries for more than 10-15 years, that is - when they migrated, they were young. Most non-migrated wives agreed, when they got married to their migrant husbands, they were very young age and spend their crucial young adulthood life in separation with their husbands which has some socio-psychological implications on them. These migrant families are having on an average of 3 children and analysis shows that there are more female children than male ones. Most children were recorded under the age of eighteen years old. Children in migrant families are much in demand right after their marriage. These children are a sense of safety and emotional security in the absence of their migrant husband, at the same time, often these leftbehind women remain engaged in taking taker of their children.

The Education level among left behind wives is another important factor. This left behind wives, holds education till school level was more than 70 percent, 12 percent were noted illiterate, and rest were recorded having professional degrees. On the other side 78 percent of migrant husband hold education beyond their primary education, 10 percent were recorded having no formal schooling and 12 percent had professional degree. Comparing the level of education of both migrant husband and non-migrant wife, and it was observed that both hold the education till school level.

Occupation plays an important key role in determining socio-economic level. Occupations are largely based on qualifications in education. Indian workers in the Gulf countries are mainly categorized into groups blue-collar jobs and white-collar jobs. Most migrant workers are higher for blue-collar jobs i.e., around 78 percent male migrants working as labor electricians, carpenters, drivers, and meson, etc., and 22 percent were recorded working as safety officers, site managers, accountants and engineers (i.e., white collars). Therefore, their occupations are largely based on the level of education qualification they have. On the other hand, around 44 percent of migrant workers earn remittances below 50,000 per month, 38 percent of migrant workers earn above fifty thousand per month, and 18 percent earn remittances above one lakh. For left-behind wives' majority of them are housewives and non-involved in any income generation activities and around 8 percent were recorded employed and earning less than fifteen thousand per month (this includes 3 women profile from Hindu religion and 1 from Muslim profile were recorded working as a schoolteacher in primary school). This too, because of their migrant husbands are remitting enough money to fulfill their household needs and various household responsibilities like childcare, cooking, washing, etc., forced left behind women to engage more with household activities.

Most migrants' families are recorded holding properties (in terms of land). In the sample household, more than 80 percent were mentioned living in a pucca house (built with engineered structure and designed to be a solid and permanent house) and fewer were recorded living in kaccha house (unengineered structure built with mud brick and straw) as well as none of the non-migrate wife 
were recorded having any property in her hand, but fewer were mentioned about owning a piece of land outside their village area.

Many of these migrants' household owned 2 wheelers (i.e., bike or scooter) or no vehicle. Most of the sample household-owned home appliances like fans, refrigerators, cooking stoves, and gas, etc., and a significant amount of income is spent on purchasing these household appliances. This ownership of household goods is also a sign of superiority or high status in society. And this appears to be attributable at least in part to working and earning abroad by a migrant member of household. Here, it can be observed that migration has contributed largely to improving the socio-economic status of the family left behind.

\section{WITH NEW RESPONSIBILITIES COMES NEW DECISION-MAKING POWER}

In a family, where one or more than one male member had migrated, woman of the same household must graduate herself enough to perform those work and tasks, which were done only by males in the household. These involve, making decisions at the household, handling money, decisions related to agricultural management, purchasing of, land, and children's wellbeing and education. The change in the degree and the direction of decision making largely depends on the composition of migrant's family system, migrant husband's continuation of employment abroad and wives' level of education. Therefore, these intervening factors i.e., family structure, husband's continuation of employment abroad, level of education, and age of wife become important in the process of decision making by women who remained in the household. For the study, it was hypothesized, women who stayed in a nuclear family system and whose husbands have migrated abroad for a longer duration enjoy more 'decisionmaking power' in the household as compared to women living in extended family system.

During the interview, the left-behind women were asked many open-ended queries to get information about what are the areas within or outside of the household they made decisions in the absence of their migrant husband. Decision making by left-behind women was recorded based on their absolute or final decision like purchasing of the food item and groceries for household, clothing, handling of remittances, spending income on renovation of house, purchasing of jewelry items, purchasing of property, ceremonies like weddings or festivals, children's education, health care.

As one of the respondents from a village called Nawada who was living in a nuclear family (had education till school level and aged 49 years, husband working for more than 18 years in Gulf) said "It is my responsibility to look after my family as my husband is not at home. He sends money every month in bank. I spend the money according to our needs and I am the person in charge of everything from buying household goods to deciding in which school my children study." Another respondent from the same village, living with her in-laws (high school passed and age 27 years old, husband migrated 5 years back) mentioned "I follow my in-law's instructions; I do whatever elders of the family decide related to household". Women living in the nuclear families gave affirmative answers in taking decisions for their primary needs in the household while women living with husband's older parents have less say in key decisions related to agriculture or big farmlands but agreed to take many decisions in the household on behalf of migrant husband's parents as they are old and weak. They are the only women left in the household for looking after them to take care of their health and daily need of their in-laws and children. Fewer women were recorded with less say in their household matters, this is so because, these women living with their in-laws, most of them are young wives having young children, less uncovered with the external network due to the conventional role of caretaker, and more dependent on another male member of the family for things as compared to women who are older in age and living in a nuclear family are more uncovered with the outer world.

One woman from village Tribirwan (living in a nuclear family, illiterate, aged 53 years old, husband migrated more than 20 years) said -: "Before he left, we were living with our in-laws and his brother's family. After my father-in-law's death, many disputes started over property among brothers. It's good that we are leaving separately from them; they have always had issues on our lands. Now we are separated because he earns good money. Mostly, all the women here handle the responsibility of the household after their husband's migration." It is quite clear from the above responder's statement they prefer to stay in nuclear family system after their husband's migration. Handling and managing remittances or income is another important area in which women make decisions. It was evident that these 
migrant husband's regular sends their income for household consumption. Either their wife's receiving the remitted amount or the elder member of the household. Those women who were living in a nuclear family were directly recorded receiving of remittance in their bank accounts and those who were living under the guardianship either their elders gave them some money, or their husband sent some money in other relative's accounts. It is interesting to note that, remittances saving was noted to be encouraged by wives in both types of households. The saved income was largely spent on either on the rebuilding or renovation of the household or payment of the debt back. In this situation, by and large migrants sending income back home helps improve the living standards of the family and social status in the society. In this whole process of managing and handling the remittance at home, encouraged women to take more financial decisions which eventually make them more financial independent in the household.

Women are mainly left behind to take care of migrant family members who remain in the house. They must take care of the well-being of the family. Therefore, they are becoming the centre in the migrant's family. Similar conclusion has been found in the study conducted by (Desai \& Banerji, 1995) on 'Male migration and left behind wives in India' that the women those are left behind have greater decision-making power in the household, especially when these non-migrant women are residing in a nuclear family system. The longer the continuation of employment of migrant husband abroad, the greater the willingness of women for living in a nuclear family system. These women who remain in the household have an effective role in decision-making for the household as they are winning in keeping various gender seclusion aside since their male truancy. These women are gaining headship without any financial contribution in the household.

Migration of their men to the Gulf region has appeared to be taking withdrawal from their isolation by the leftbehind women in the household. Husband's migration has created required circumstance which enforced them to shoulder more roles and responsibilities and mobile. An assumption was made, women in a nuclear family turning themselves into de facto household women headship (De-facto female-headed is a situation where due to migration the male head of the family is temporarily absent from the household and female- headed women may acquire more decision-making power \& control and gain access over resources (Keyes, et al. 1990)) and which may largely cause them with new responsibilities and increased workload on their shoulders. For addressing this assumption, I compared women living in nuclear families with women living with their in-laws in extended families. As a woman living in a nuclear family mentioned that after many years of her husband migration, now she can frequently pay visit to her parent's house, in contrast to another woman who was living with in-laws mentioned that she had to take permission before visiting her parent's house. Women who reside in the nuclear family system were observed to be having more mobility and tend to visit their parents, relatives, and friends more often than women in extended family system. One might notice this increased in the decision-making and movement of the women in the household is due to the income they have accessed through their migrant husbands. They are acting as primary or sole decision-makers and in charge of handling remittance to buy groceries for the household. While managing these responsibilities, there are greater chances of women becoming more autonomous in terms of having economic independence which influence them to remain more involved in decision making process in the household. Hence, these burdens of new roles and responsibilities also give them a great amount of stress and anxiety.

Women play a central part during and after their husbands' emigration abroad. When their husband emigrates, they stay connected with their families (i.e., parents, wives, and children) through technology. Frequent communication with migrant husband through mobile phones and social networking plays an important role in making decisions in the household. On asking the non-migrated women during the interview in villages about if they take their migrants' husbands advice or permission before making any decision and spending remittances, one of the non-migrant respondents living with her children mentioned "Mainly, I make the decisions alone, may be because he is not always available. I don't know! There are some areas I must ask him about it, I must listen to him, and he is the bread earner" another woman who was living with her in-law said, "I live with my children and whatever I needed take any decision. I take my husband's advice; I never take any decision without his advice". Women from these villages were recorded to be frequently consulting with 
their husbands through mobile phones on major matters related to the household like house renovation, giving loan or payment of loan to others, and purchasing of new electronic for household. Consulting with their husbands on various household matters make much more impact of women on her decision making and her relationship with husband. As one woman said I always remind my husband about our pending loans and expenditures for household, similarly another wife of a migrant mentioned that she always encourages saving to his husband so that later they can have their own house in a city. Migrants' wives often discuss and share all kinds of matters with their husband, related to household activities, visiting any relatives, elder parents and kin's wellbeing and children health \& education, death of someone in the village, spending on house renovation and repaying of loans. Even sharing and discussing most of her day-to-day activities with husband, many times wives don't talk about their own personal savings, which they save for themselves and spend according to their needs. One of the respondents said sometimes I don't let him know about my extra saving from income. I spend on myself and on my children.

Despite this frequent communication with their migrant spouse, they are unable to recompense with the lengthy duration of their stay abroad. Even though these wives considered their spouse migration as worth enough to raise their living standard and economic status as well as influence them in decision making process. Yet, at the same time, their husband's migration makes them feel lonely many times. Those who live in an extended family are lonelier but having less stress and anxiety as they share less burden of responsibilities as compared to wives in a nuclear family. These women also revealed that fear to face criticisms for not being able to take care of children and house in their husband's absence. So, this also could unfold stress on wives left behind on taking decisions for their family.

In looking after the migrant husband's family and in completing new roles and responsibilities, these leftbehind women gain new skills in handling and managing work, experiencing social situations, and becoming aware of their own capabilities inside and outside the household. Therefore, within the light of limits drawn by their husband or husband's parents and the traditional constraints, these women are working towards succeeding in upholding their agency. The experience and managing skills they are learning due to their husband's absence from the household make them empowered (In this paper, the word empowerment is used in a very particular meaning, for instance, a person's sense of effectiveness and capabilities and in the light of wife's role in decision making and responsibilities and her mobility outside the family and community), helping in their personal and social transformation.

\section{On Women's Mobility}

The long absence of male from the house often leads women to substitute with the new roles and responsibilities which are traditionally being linked up with men and thereby challenge the customary gender roles and division of labor. While these extra social and financial responsibilities may lead to greater stress, but "the potential also exists for such income-generating activities to increase the autonomy and empowerment of women" (United Nations, 2005), and managing remittances at home may become a contemporary source for financial independence and power for women who remains at home.

The impact of male emigration abroad on the women who remain in the household can be considered encouraging for their mobility in the Gopalganj district. These womenable to transcend their restricted social boundaries. During the interview to non-migrating women were asked, if their mobility within and outside of the district had increased due to their husband's emigration. As many non-migrant respondents gave affirmative answers. In the past, where women principally had been restricted to a household only, now these left behind women are found reasonably mobile due to their husbands' migration abroad.

One of the young wives responded (28 years, staying with her husband's parents, from village Indarwan) I talked mentioned within one month of their marriage her husband left for the Gulf and left her with in-laws. She must ask or take permission from her in-laws before visiting doctor or meeting relative or friends. She must cover herself with cloth (veil) before going outside as she was newly married. Further, she mentioned in whenever she visits her parent's house, she feels more unrestricted and mobile. In a society, where there is a stronghold of patriarchy, women's movability was restricted within the house under peer surveillance and were not allowed to be exposed to outsiders and 
enforced rigid socio-cultural expectations for women like veiling. A woman from Yakoon Takira village age 32 years, living with children told "I go outside like market to buy medicine, food or for shopping, bank more often, I have to take care of my children's need and myself", another woman (44 year, living in the extended family) from Indarwan village said, "I live with my in-laws, now there is less restriction on me, I take them to hospitals for their check-up, visit relatives, purchase vegetables and clothes by myself".

From the left-behind women's response, it is clear their husband migration had influenced them to shoulder more responsibilities and become more mobile. These left-behind females often visit markets to buy groceries, clothes, food, and school stationery for their children, banks to manage their remittances, children's schools, and hospitals. I found that left-behind women who stay in nuclear families are more mobile and frequently pay visits to their parent's house or relatives and are freer to attend ceremonies or family functions as compared to left behind women who need their In-laws permission before visiting maternal family or functions. This is so because these women in nuclear family have direct access to the income which they can easily spend on travelling or spend on ceremonies. Despite the situation in the village where there are few or no men in the house, increased burden of responsibilities like from visiting children's schools, banks, markets, to buy vegetables are on women's shoulders, they affirmatively respond they had become empowered, had gained self-confidence, and transforming their lives by handling these responsibilities.

Similar results were also noticed in a study conducted on male migration in Saora Tribe, (Menon, 1995) found that after being migrated to a new place of earning, migrants continue to hold a knot on their assets and families back home through their non-migrant wives who stays home and therefore represents women as a supporter of tradition and benefactor of family assets. She further argues that these addition burden like taking care of children and household, health concerns encourage wives to remain stayed at home and gives more freedom to their husband to move out. (Gulati, 1993) on male migration from Kerala to Gulf, results from her study indicates that migration of their men has influenced women's mobility outside the home, desolates form social isolation, and reconnect with organizations and institutions. This eventually helps them to gain a greater sense of self-confidence and take over more power and authority.

\section{On Women's Attitude}

One of the principal inquiries on non-migrant women was that their husband's truancy abroad has emancipated them from their presumed longestablished conventional beliefs, values, and behavior or encouraged women to "renegotiate patriarchal constraints". Another analysis of the study was to measure the attitude of women who reside in the household after their husband's long absence. It was assumed that the truancy of husbands abroad and an influx of remittance back home to the left-behind women have had made an effect on the women's role and attitude towards traditional culture and practices, as well as household activities and affairs. Women were asked several questions related to household task like cooking, washing clothes, cleaning, looking after children and old parents of husband, etc. whether done by them alone or taking help from others like by hiring a helper. In non-migrant houses, majority of non-migrant women answered affirmatively that they themselves do their household tasks and few were agreed on hiring a helper when a need arises like women feel sick. One respondent from village Tribirwanliving with her inlaws and 2 children said, "My daughter is small and I often hire a helper who can assist me in household chores because doctor had told me for bed rest due to my health issues" Another women living with her migrant husband parents and her 3 daughter and 1 son from the same village told "It is very difficult sometimes in his absence to manage household. I look after every work or involve my elder daughter in few household chores". Similarly, another non-migrant woman living with 3 children from village Nawada said "I do all the household chores, from cooking to washing, who else would do". It was evident, despite of the fact, getting inflow of remittance back home these women seem to be more involved in the traditional household activities without taking much outside help or employed household help for themselves. Thus, the long duration of the husband's truancy and flow of remittance doesn't seem to have much affected the role of women in conducting the household activity.

Migration of male family member and migrants' remittances are also act as an important factor in breaking various rigid cultural traditions and practices 
like girl child education, dowry system, early marriages of girl, and husband helping hand in household chores during their visit home back. Many women said their husband's migration had made a positive impact on their girls' education. As Most of them both migrant husband and non-migrant wives are literate and feel the need for education for their children, they wanted their children to pursue of good education, especially girls. I found that among these 50 sample households, despite improving their standard of living in the household after many years of husband's migration, supervision on children's health and education was given special attention by migrants. They frequently make enquiries to their wives about their children health and education status. From what I observed from these sample households, women themselves are very concerned about their children's education and health. They hire an extra tutor for their children and never hesitate to spend extra income on their health when they fall sick. This is so because they are more concerned for their kid's future and preference of partner for marriage (especially for girl marriage). One respondent (living with mother-in-law and 1 daughter, rest of her 2 kids are studying outside of district) from Gopalganj Town area said, "my daughter wants to be a doctor, she is studying in Patna". There is husband migration also gives them the opportunity to send their children for higher studies outside of districts or states. A very few respondents said they want (or some are already studying) their daughters to get high education outside of the district. This widespread migration of male from Gopalganj district's interviewed villages had led to significant changes in traditional practices like marriage. On asking one-woman age 39 years from YakoobTakiya village said, "my in-laws and husband are against dowry", another woman aged 42 years from village Tirbirwasaid "my daughters are studying, and we want her to get married once she completes their studies".

Male out migration also changes social attitude towards gender roles in the household. In conventional societies, where men do not engage in household work such as cooking, cleaning, and child rearing, domestic helping such tasks were believed to be restricted to women only. Many responded mentioned when their husbands visit them home back, they don't allow them to wash and iron their clothes, instead they themselves do their work. As a woman (living with her children, age 47 years) mentioned "he cooked occupationally, we eat together with family", another woman (living separated with her in-laws, age 51 year) said, "When he comes, he handles much work like looking after children education, we visit relatives together". Therefore, evidently, husbands' absence and remittance inflow have not much affected role of women in handling household tasks. On the other hand, it had positively resulted that these women left behind breaking traditional practices among nonmigrant families and within community and slowly and steadily their husbands' out-migration is bringing changes in both their social status and social attitude. Similar results were noticed in Hondagneu-Sotelo's (1992) study she finds that migrants who stay for a longer duration in the US called 'bachelor communities', uncovered various skills like cooking, cleaning, and other domestic chores. When they were reunified with their family members at home, they begin to continue to these household chores and other activities, and such households had a less traditional division of labor. Jetley (1987) finds that in rural Uttar Pradesh, State of India, when male migrants came back home for a temporary period, they occasionally assist their wives in household chores, while living in the city they are used to cooking, cleaning, and washing

Therefore, it is interesting to note that their husband's truancy had made these women to negotiate and modify gender roles through their mobility outside the community and are exposed to various social institutions. Their husband's emigration abroad has offered non-migrant women mobility and autonomy. These women said that their task required freedom of physical mobility and independence. Due to the existing religious principles, traditions, and socio-cultural taboos in the society and among migrant's families for instance low participation of women in employment, pardah system, gender discrimination and girl child education. Thus, migration of their male has helped women to loosen gender or patriarchy constraints and take one step forward towards transforming and empowering their lives.

\section{CONCLUSION}

Male migrating to the Gulf region has had a huge impact on left-behind women. The paper tried to find out the socio-economic impact of male migration from Gopalganj District, Bihar (India) on left-behind women's decision-making power, mobility, and attitude that helps them to be empowered. It also tried to understand how 
the physical absence of their husbands and the heads of the home, and influx of remittance have positively impacted the lives of these women as they are now able to renegotiate their traditional social roles and responsibilities predestined by patriarchy. The paper is of the opinion that the process of being away from homes and earning enough money due to migration has helped to loosen the rigidities of the patriarchal structure. One of the findings of the study is that the traditional social status of women and gender relations between wife and husband seem to change due to their husbands' migration to the Gulf countries as they are somehow able to negotiate their social role in the patriarchal society. The increased social status of women and seemingly changed wife-husband relations exhibited through their decision-making power in the household, financial independence to some extent in terms of where and how expanding money, and increased mobility in the female head of household, could unfold the female's agency on a whole. These leftbehind wives enjoy autonomy, better access, and control over resources on the other hand, and one other, they are becoming more self-reliant and self-confident. This change has given them a sense of self-dependence and financial independence that they are able to manage their lives, children, and home These results were more visible on those left behind women who are living in the nuclear family system and a little less visible on wives residing with their in-laws in extended type family composition as most of them are young wives having young children, less uncovered with the external network due to conventional role of caretaker and living under guardianship.

The male migration has also positively influenced leftbehind women's mobility and their exposure to the outside world, but their participation in employmentgenerated activities is still very much limited. It was evident from the study that frequent communication between migrant husbands and non-migrant left behind wife have had improved their relations and helped to cope up with their stress. This is unlike the pre-modern pre-technological era when there was no quick communication mode through which could connect with their absent loved ones and release psychological anxieties and that had led them to express their feelings in folklores. However, time has changed the physical absences are compensated by virtual presence through modern communication technology.
The study also finds that these women, while being within the limits of their religious beliefs, are becoming more mobile, encouraging education in children, especially girls' education, in some cases visiting faraway places outside the district handling more remittance in the absence of their husbands. Therefore, this temporary separation of their spouse in the patriarchal society has been favorable to the women, enhancing their bargaining power, and their ability to renegotiate the patriarchal constraints as efficient agents in managing and supervising complex roles and responsibilities. Thus, male out-migration abroad is transforming their lives socially as well as economically.

\section{REFERENCES}

Census. (2011). Population Census 2011. https://www.census2011.co.in/census/state/bih ar.html.

De Haan, A. (2002). Migration and Livelihoods in Historical Perspective: A Case Study of Bihar, India, Journal of Development Studies, 38(5), 11542

Desai, Sonalde, and Manjistha Banerji. (1995). Negotiated Identities: Male Migration and Leftbehind Wives. Journal of Population Research, 25, 337-55.

Deshingkar, P. and Start, D. (2003). Seasonal Migration for Livelihoods, Coping, Accumulation and Exclusion, Working Paper 220, London: Overseas Development Institute

Gulati, Leela. (1993). In the Absence ofllzeir Men: The Impact of Male Migration on Women. New Delhi: Sage Publications.

Hondagneu-Sotelo, Pierrette. (1992). Overcoming Patriarchal Constraints: The Reconstruction of Gender Relations among Mexican Immigrant Women and Men. Gender and Society, 6(3), 393415. Sage Publications, Inc. https://www.jstor.org/stable/189994.

Keyes, Mascarenhas, Stella, Leela Dube, and Rajni Palriwala. (1990). Structures and Strategies: Women, Work and Family. New Delhi: Sage Publications.

Menon, Geeta. (1995). The Impact of Migration on the Work and Status of Tribal Women in Orissa", in Loes. New Delhi: Sage Publications.

United Nation (UN). (2005). 2004 World Survey on the Role of Women in Development. Survey, New York: United Nations Publication, 17.

Organization, International Labour. (2018). International 
Labour Migration Statistics (ILMS) Database for South Asia. Publication, New Delhi: International Labour Organization, https://www.ilo.org/wcmsp5/groups/public/asia /robangkok/sronew_delhi/documents/publicatio n/wcms_645314.pdf.

Roy, Archana K. (2011). Distress Migration and ' Left Behind' Women. New Delhi: Rawat Publications.
Surinder, Jetley. (1987). Impact of Male Migration on Rural Females. Economic and Political Weekly 22 (44), WS47-WS53.

Zachariah K.C \& Mathew, E.T. \& Rajan, Iruday. S. (2000). Socio-Economic and demographic consequences of migration in Kerala, Centre for Development Studies, Trivendrum Working Papers 303, Centre for Development Studies, Trivendrum, India.

Publisher's note: EScience Press remains neutral with regard to jurisdictional claims in published maps and institutional affiliations.

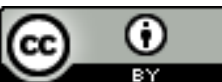
use, sharing, adaptation, distribution and reproduction in any medium or format, as long as you give appropriate credit to the original author(s) and the source, provide a link to the Creative Commons license and indicate if changes were made. The images or other third-party material in this article are included in the article's Creative Commons license, unless indicated otherwise in a credit line to the material. If material is not included in the article's Creative Commons license and your intended use is not permitted by statutory regulation or exceeds the permitted use, you will need to obtain permission directly from the copyright holder. To view a copy of this license, visit http://creativecommons.org/licenses/by/4.0/.

(C) The Author(s) 2020. 